\title{
Hvordan kan vi forstå barns tilfredshet med egen involvering i
}

\section{foreldremekling?}

\author{
Astrid Strandbu, Renee Thørnblad og Anita Salamonsen
}

Astrid Strandbu er professor i pedagogikk, Institutt for lærerutdanning og pedagogikk, UiT Norges arktiske universitet.

Astrid.strandbu@uit.no

Renee Thørnblad er professor i sosiologi, Regionalt kunnskapssenter for barnevern og barn og unges psykiske helse Nord (RKBU Nord), UiT Norges arktiske universitet.

Renee.thornblad@uit.no

Anita Salamonsen er professor i sosiologi, Regionalt kunnskapssenter for barnevern og barn og unges psykiske helse Nord (RKBU Nord), UiT Norges arktiske universitet.

Anita.salamonsen@uit.no

UiT Norges arktiske universitet, Postboks 6050 Langnes, 9037 Troms $\varnothing$

\section{Sammendrag}

I forskningsprosjektet «Høring av barn i mekling» har vi studert meklinger hvor barn og ungdom har vært involvert i meklingsprosessen gjennom en samtale med mekler uten foreldrene til stede. Barn og unge er i all hovedsak svært tilfredse med å delta. Hvordan kan vi forstå denne tilfredsheten? Og hva sier dette om kulturelle kontekster for barndom i dag og barns posisjon i meklingskonteksten? I denne artikkelen undersøker vi slike spørsmål ved å utforske hvilken mening og kvalitet barn og unge tilskriver egen involvering $\mathrm{i}$ foreldremeklingsprosessen. Artikkelen baserer seg på analyser av et åpent spørsmål i spørreskjema fylt ut av 111 barn og unge som har hatt en egen samtale med mekler. Analysene er teoretisk forankret i barndomssosiologiens syn på barn som aktører og en hermeneutisk forståelse av mening. Resultatene viser at barn og unge tilskriver egen deltakelse mening knyttet til både meklingsordningen, retten de har til å delta, og behov for bearbeiding. ${ }^{1}$

\footnotetext{
${ }^{1}$ Takk til ansatte ved hhv. Grenland og Tromsø familievernkontor for godt samarbeid og innspill til artikkelen. Takk også til redaksjonen og anonym fagfelle for svært nyttige innspill i revideringen av artikkelen.
} 


\section{Nøkkelord:}

samlivsbrudd, mekling, barns deltakelse, mening, differensiering og digitalisering av meklingstjenesten

\section{Introduksjon og problemstilling}

Som eneste land i verden har Norge lovfestet én time obligatorisk mekling for alle gifte og samboende foreldre som skiller lag og har felles barn under 16 år (ekteskapsloven $\S 26$ og barneloven § 51). Foreldre kan få tilbud om opptil 7 timer mekling ved behov. Det er obligatorisk mekling også når foreldre ikke kommer frem til enighet om bosted og samvær og den ene forelderen stevner den andre for retten. ${ }^{2}$ Dette omtales i fortsettelsen som henholdsvis bruddmekling og foreldretvistmekling. Formålet med alle meklinger er å komme frem til en skriftlig avtale om foreldreansvar, fast bosted og samvær som er til barnets beste.

Den norske barndommen utfolder seg i et velferdssamfunn hvor idealer som likeverd, likestilling og demokrati står sentralt. Norge kan beskrives som et barnesentrert samfunn. I den internasjonale målingen Kids Right Index, en rangering av rundt 180 land i verden, har Norge de siste tre år vært på henholdsvis andre, første og sekstendeplass. ${ }^{3}$ Fem ulike kriterier på en god barndom blir vurdert: liv, helse, utdanning, beskyttelse og en femte samlekategori som blant annet omfatter retten til deltakelse i beslutninger som har betydning for barns hverdagsliv. Barns rett til deltakelse står sterkt i Norge. Som et av de første landene i verden ratifiserte Norge i 1991 FNs barnekonvensjon av 1989, og konvensjonen ble inkorporert i norsk rett fra 2003. ${ }^{4}$ Barns rett til å uttale seg i mekling ved samlivsbrudd er nedfelt $\mathrm{i}$ artikkel 12 i Barnekonvensjonen, $\S 31$ i lov om barn og foreldre og i § 104 i Grunnloven.

Barn i Norge involveres og involverer seg i kontekster der de tidligere var objekter for beslutninger som ble fattet. Et eksempel på dette er endringen av meklingspraksisen når foreldre skiller seg. Når foreldre skiller lag, skal det tas en rekke beslutninger som har betydning for barns hverdagsliv, og ifølge FNs barnekomité er separasjon og skilsmisse en av de viktigste sakene som krever at barnets rett til deltakelse innfris (General Comment No. 12 (2009) punkt 50 og 52). I forbindelse med mekling er det foreldrene som har ansvar for å

\footnotetext{
${ }^{2}$ Etter den første obligatoriske meklingstimen får foreldrene en meklingsattest. For å gå til sak må foreldrene ha en meklingsattest som ikke er mer enn 6 måneder gammel (jamfør barneloven $\S 54$ siste punktum).

${ }^{3}$ https://www.kidsrightsindex.org/Portals/5/KRI\%202019/The\%20KidsRights\%20Index\%202019\%20Report.pdf ?ver=2019-05-09-150422-647

${ }^{4}$ Lov nr. 30/1999.
} 
ivareta barns uttalerett (BLD, 2008). Det er ikke lovfestet i barneloven eller pålagt i meklingsforskriften at mekler skal høre barna. Mekler kan snakke med barn, men dette er ikke et juridisk krav. Mekler skal imidlertid informere foreldrene om barnets rett til deltakelse og foreldrenes plikt til å snakke med barnet om bruddet og den forestående familieforandringen (jf. meklingsforskriftens $\S 2$ ). En forutsetning for barns deltakelse i denne konteksten er at begge foreldrene samtykker til dette.

Tradisjonelt har det vært meklet om barn og barns beste, uten at barn har vært direkte involvert. Eksempelvis var barn involvert i kun $2 \%$ av alle meklinger i 1997 (Ekeland og Myklebust, 1997), mens barn var involvert i 4 \% av meklingene i 2011 (Ådnanes mfl., 2011). Barns posisjon i meklingskonteksten er gradvis styrket de siste årene. I 2014 var barn involvert i 7 \% og i 2015 i $14 \%$ av alle meklinger (Bufdir, 2015; Bufetat, 2016a). Antall barn involvert de siste årene har fortsatt å øke til 21, 4 \% i 2017 (Bufdir, 2018) og 26 \% i 2018 (Bufdir, 2019). Så langt i 2019 (målt 31.7.19) viser nasjonal statistikk at barn har vært involvert i $28 \%$ av alle meklinger. Politisk er det i 2019 en målsetting at barn skal delta i 30 $\%$ av alle meklinger (BLD, 2018).

Endring i syn på barn, politiske føringer som sikter mot å styrke barns deltakelse i mekling (Bufdir, 2016; BFD, 2019), og utvikling av modeller med tydelige strukturer for involvering av barn i meklingsprosessen har bidratt til at stadig flere barn involveres i meklingsprosessen. En meklingsmodell som har hatt særlig stor betydning, er «Barn i mekling» (BIM). I BIMmodellen har barnet en egen samtale med mekler alene før meklingen mellom foreldrene gjennomføres (Bufetat Region Sør, 2016). BIM-modellen omtales nærmere under neste overskrift. Datamaterialet denne artikkelen baserer seg på, er innhentet i forskningsprosjektet «Høring av barn i mekling» (heretter omtalt som HBIM-studien). I HBIM-studien har vi samlet data fra 250 BIM-meklinger gjennomført av 21 meklere ved 4 kontorer i 2 av landets regioner i perioden 2012 til 2015. Studien er godkjent av Norsk senter for forskningsdata. I en tidligere del av studien har vi publisert resultater basert på kvantitative analyser av 345 barn og unges (heretter barns) tilfredshet med å være involvert i meklingsprosessen. Vi undersøkte her sammenhengen mellom barnas tilfredshet med egen deltakelse og type mekling, konfliktnivå og grad av problembelastning i familien. Resultatet var at barna er tilfredse med å være involvert, uavhengig av om konfliktnivået er høyt eller lavt, om det er bruddmekling eller foreldretvistmekling, og om grad av problembelastning er høy eller lav. Barna anbefaler også at andre barn skal inkluderes i meklingsprosessen (Strandbu mfl., 2016). Spørsmålet vi 
stiller i denne artikkelen, er hvordan vi kan forstå barnas tilfredshet. Dette undersøker vi ved å reise følgende problemstilling: Hvilken mening og kvalitet tilskriver barn det å være involvert i meklingsprosessen?

Ulvik (2009) argumenterer for at begrepsdiskusjonen om barns deltakelse ikke bare er av akademisk interesse, men også kan ha praktiske implikasjoner for politikere og profesjonsutøvere, og på denne måten bidra til forbedring av barns liv og utvikling. Hun skriver: «Hvordan 'deltakelse' defineres vil ha betydning for hvordan praksiser kan begrunnes og utformes» (s. 1148). Meklingspraksisen er i endring. Spørsmål knyttet til barns posisjon i mekling, så som når i meklingsprosessen barnet skal involveres, hvorvidt mekler skal snakke med barnet alene, og om det er meklingssaker hvor barnet ikke skal snakkes med på grunn av enten svært lavt eller svært høyt konfliktnivå, er gjenstand for diskusjon både fagpolitisk og i praksisfeltet. Formålet med denne artikkelen er å bidra med forskningsbaserte innspill til slike diskusjoner ved å rette fokus mot hvilken mening det har for barn å være involvert $\mathrm{i}$ meklingsprosessen. Mening er et flertydig begrep. Mening kan forstås synonymt med aktørens synspunkt. Mening kan også oppfattes som det som oppleves som meningsfullt og utgjør kvalitet for aktøren i en gitt kontekst. Disse to tilnærmingene kan også gå over i hverandre, ved at det å gi uttrykk for egne meninger oppleves som meningsfullt. Vår problemstilling springer ut av en hermeneutisk forståelse av mening i studiet av sosiale fenomener. Innenfor hermeneutikken fortolkes mening både som uttrykk for et individualistisk aktørperspektiv og som noe som reflekterer en felles, kollektiv, historisk og kulturell kontekst (Guneriussen, 1999).

Videre i artikkelen redegjør vi for foreldremeklingsfeltet i endring. Deretter presenteres datamaterialet, analyseprosessen og resultater. I diskusjoner og avsluttende konklusjon ses våre resultater i lys av pågående endringer i meklingsfeltet, med digitalisering og differensiering av mekling.

\section{Foreldremekling, et meklingsfelt i endring}

Den markante økningen fra 2014 i antall barn som er involvert i meklingskonteksten, kan ses i lys av utvikling og spredning av BIM-modellen. BIM-modellen ble utviklet av mekler Gjertrud Jonassen ved Grenland familievernkontor i 2012. I løpet av 2013 bidro Jonassen med opplæring i modellen ved de fleste av landets familievernkontorer. Formålet med BIM- 
modellen er å sikre barns deltakelse i forbindelse med brudd- og foreldretvistmeklinger. BIMmodellen er av Anna Nylund (2019) vurdert fra et juridisk perspektiv som et viktig steg mot å oppfylle barns rett til deltakelse. Når det mekles etter BIM-modellen, starter mekleren med å gi kort, felles informasjon til foreldre og barn om hva mekling er, hvordan mekling etter modellen skal gjennomføres, og hva som er formålet med samtalen mekler skal ha med barnet alene (heretter barnesamtalen). Deretter forlater foreldrene rommet. Barnesamtalen er strukturert etter tre spørsmål. Det første spørsmålet («Hvordan har du det?») har som formål å gi barnet emosjonell støtte ved at barnet får uttrykke egne følelser. Det neste spørsmålet («Hva er det som skjer?») skal hjelpe barnet til å forstå hva som faktisk skjer, samt sette egne ord på situasjonen barnet og familien befinner seg i. Det tredje spørsmålet («Er det noe du vil si til foreldrene dine?») er fremtidsrettet. I samtalen med mekler gis barnet mulighet til å tenke igjennom og uttrykke både hvordan han/hun har det og hvordan han/hun ønsker å ha det fremover. Barnet bestemmer selv hva av dette mekler skal skrive ned som barnets budskap til foreldrene. Meklingen mellom foreldrene, hvor barnet ikke er til stede, starter med at mekleren leser barnets budskap høyt for foreldrene. Når meklingsmøtet mellom foreldrene er avsluttet, hentes barnet inn igjen og får informasjon om hva som er bestemt, eventuelt at foreldrene skal tilbake for å jobbe mer med avtalen. Barnesamtalen tar ca. 20-30 minutter, og hele BIM-meklingen varer i ca. 1,5 time. Foreldre og barn inviteres til en evalueringssamtale etter et halvt år. Evalueringssamtalen gjennomføres etter samme struktur som selve meklingen (Bufetat Region Sør, 2016).

En annen markant endring i meklingsfeltet er innføring av digitalisering og differensiert mekling. ${ }^{5}$ Barne-, ungdoms- og familiedirektoratet startet i 2014 arbeidet med å utvikle og standardisere meklingstilbudet ved foreldremekling. Våren 2018 fikk alle familievernkontorer opplæring og tok deretter i bruk den nye meklingsordningen. Formålet var effektivisering og mer standardisert og målrettet bruk av ressurser tilpasset familiers ulike behov (NOU 2019: 20 s. 113). Differensieringen innebærer at meklingen gjennomføres ulikt ut fra foreldrerapportert konfliktnivå og problemkompleks. Prosessen starter med at en av foreldrene tar kontakt med familievernkontoret for å begjære mekling. I samtalen med den kontorfaglig ansatte svarer forelderen på syv spørsmål vedrørende uenighet om bosted, samvær og foreldreansvar, konflikter i foreldresamarbeidet, hvorvidt foreldrene stoler på

\footnotetext{
${ }^{5}$ Redegjørelse for differensieringen og digitaliseringen og diskusjon av konsekvenser av den nye ordningen bygger på samtaler med og informasjon innhentet fra ansatte ved to av landets familievernkontorer. 
hverandre, og hvorvidt de har vært i retten med foreldretvistsak. De to siste spørsmålene er relatert til rus og/eller vold, og om dette er hensyntatt i planlegging av bosted og samvær for barnet. Den andre forelderen blir oppringt av familievernet og blir bedt om å svare på de samme spørsmålene. Differensieringen blir gjort på bakgrunn av disse to samtalene. En algoritme regner ut en sum basert på svarene foreldrene gir, og på bakgrunn av summen skilles det mellom A-, B-, C- og det som i differensieringen omtales som risikomeklinger. Ameklinger er bruddmeklinger med lavt konfliktnivå hvor svarene på spørsmålene indikerer at foreldrene stort sett er enige om bosted og samvær, har tillit til hverandre, og hvor foreldresamarbeidet fungerer. B-meklinger er bruddmeklinger mellom par med moderat konfliktnivå hvor det er noe uenighet om bosted og samvær og noen utfordringer i foreldresamarbeidet. C-meklinger kan være både bruddmeklinger og foreldretvistmeklinger. Det blir ei C-mekling dersom en av foreldrene svarer ja på spørsmål om uenighet om bosted og samvær og utfordringer og konflikter i foreldresamarbeidet, eller foreldrene har vært $\mathrm{i}$ retten med foreldretvistsaker. Dersom minst en av foreldrene har svart ja på at det er uenigheter om bosted, samvær og foreldreansvar og utfordringer og konflikter i foreldresamarbeidet, og dette har vart i mindre enn 6 måneder, er det ei B-mekling. Ved samme svar, men hvor dette har vart i mer enn 6 måneder, er det ei C-mekling. Dersom en av foreldrene har svart «ja» eller «vet ikke» på spørsmål om rus og/eller vold, kategoriseres saken automatisk som en risikomekling, selv om foreldrene har svart ja på at de stoler på hverandre og samarbeider godt. C-meklinger og risikomeklinger gjennomføres tilnærmet likt. Det er to meklere involvert, og det planlegges en prosess med ulike fokus i hver samtale tilpasset foreldrenes behov.

Innkalling til mekling sendes ut digitalt etter at differensieringen er gjennomført. I innkallingen informeres det om barns behov for og rett til å få uttale seg i saker som angår dem. Videre anbefales det at barn i skolepliktig alder gis anledning til å delta i mekling, under forutsetning av at de selv vil og at foreldrene er enige om dette. I A- og B-meklinger (hvor informasjonen som sendes ut er lik) anbefales at barn er med i første meklingstime. I Cmeklingene og risikomeklinger informeres foreldrene om at familievernet ønsker å treffe foreldrene uten barn i første meklingstime for å kunne forberede møtet med barnet best mulig. En forutsetning for barnets deltakelse i C-meklinger og risikomeklinger er følgelig at foreldrene takker ja til flere meklingstimer enn den ene obligatoriske timen. 


\section{Metode, datamateriale og utvalg}

Datamaterialet er samlet inn ved bruk av et kort spørreskjema fylt ut av barn umiddelbart etter barnesamtalen i BIM-meklinger. Barna fylte ut spørreskjemaet på venterommet på familievernkontoret. De yngste barna fikk hjelp fra kontorpersonalet ved behov. Spørreskjemaet er på én side og består av seks spørsmål: fem spørsmål hvor barna krysset av på en visuell, analog skala, og ett åpent spørsmål. Alle spørsmålene omhandler barns erfaringer med å være involvert i meklingsprosessen. ${ }^{6}$ Datamaterialet for denne artikkelen er det åpne spørsmålet: «Skriv her hvis det er noe mer du vil si om det å være med til mekling.»

Datamaterialet er samlet inn i perioden 2013-2014 i 213 meklinger som omhandlet til sammen 346 barn som hadde vært med til første meklingstime. ${ }^{7}$ Av disse var det 340 barn (98,3 \%) som svarte på ett eller flere spørsmål på spørreskjemaet, og 134 barn som også svarte på det åpne spørsmålet. Av dem som svarte på det åpne spørsmålet, er det 23 barn som av ulike årsaker utgår fra datamaterialet. Enkelte skrev at de ikke hadde noe mer å si om det å være med til mekling. Andre svarte ikke på spørsmålet, men uttalte seg om andre forhold knyttet til foreldrenes samlivsbrudd og egen livssituasjon. Eksempelvis uttrykte en gutt på 11 år at han ikke ville at mamma eller pappa skulle få ny kjæreste. Et annet eksempel er ei jente på 8 år som skrev at det er greit at foreldrene flytter fra hverandre. Utvalget utgjør følgelig 111 barn, dvs. 32,6 \% av det totale utvalget. Datamaterialet består av tekster, sjelden lengre enn to-tre setninger. I tillegg består datamaterialet av symboler som smilemunn, surmunn og hjerte, noen få ganger bare et symbol, men som oftest symbol i tillegg til tekst.

\subsection{Utvalget}

Barna som deltok, var rekruttert fra meklinger hvor det ikke var selektert verken for konfliktnivå, problembelastning eller type saker. Alle som gjennomførte en BIM-mekling ved de fire kontorene i perioden datainnsamlingen ble gjennomført, fikk tilbud om å delta $\mathrm{i}$ studien. BIM-modellen er utviklet for barn i alderen 7 til 16 år. Meklerne erfarte imidlertid at

\footnotetext{
${ }^{6}$ På en visuell, analog skala setter informanten kryss på en linje (i dette tilfellet fra surmunn lengst til venstre og til smilemunn lengst til høyre). Det som måles i dette tilfellet, er graden av barns tilfredshet med å være involvert i meklingsprosessen.

${ }^{7}$ Størstedelen av dataene i HBIM-studien ble innhentet i perioden 2013-2014 gjennom spørreskjema fylt ut av barn, foreldre og mekler i 213 meklinger. I tillegg består dataene også av budskap fra barn i saker innhentet i 2012. I tidligere publikasjoner basert på analyser av barns budskap er N $=250$ (Strandbu og Thørnblad, 2015). Det er i tillegg gjennomført individuelle, kvalitative intervjuer og fokusgruppeintervjuer med meklere i 2014 og oppfølgende individuelle intervjuer med meklere i 2015.
} 
også småsøsken og storesøsken ønsket å delta. De 340 barna i de 213 meklingene som har fylt ut spørreskjema, var mellom 4 og 18 år. Det var like mange gutter som jenter og flest 12åringer. Gjennomsnittsalderen var 10,8 år. De som svarte på det åpne spørsmålet i spørreskjemaet, var nærmere ett år eldre enn dem som ikke svarte på dette spørsmålet. Av guttene som deltok i studien, var det 24,1 \% som også svarte på det åpne spørsmålet, sammenlignet med 39,8 \% av jentene. Deltakerne i studien er rekruttert fra både bruddmeklinger og foreldretvistmekling. Av utvalget på 213 meklinger var det $70 \%$ bruddmeklinger og $30 \%$ foreldretvistmeklinger. Barnevernet var involvert i 11,3\% av meklingene. I 19,7 \% av meklingene hadde mekler krysset av for ett eller flere belastende forhold (rus, vold, psykiatri, omsorgssvikt og meldt til barnevernet). På en skala fra $0 \%$ konflikt til 100 \% konflikt var meklervurdert konfliktnivå i gjennomsnitt på 37,3 \%. Guldbrandsen og Tjersland (2013) finner at meklere er treffsikre i sin vurdering av konfliktnivået mellom foreldrene ved innledningen av et meklingsforløp. Det er ingen signifikante forskjeller når det gjelder type mekling, konfliktnivå, meldt til barnevernet eller andre belastende forhold mellom utvalget i denne delen av studien basert på 111 barn i 85 saker sammenlignet med det totale utvalget (340 barn i 213 saker). Utvalgets størrelse og sammensetning sannsynliggjør at resultatene har gyldighet utover dem som har deltatt $\mathrm{i}$ alle de ulike deler av studien. ${ }^{8}$ Datamaterialet er samlet inn før praksisen med differensiering og digitalisering ble innført våren 2018. Ut fra meklervurdert konfliktnivå og avkryssing for andre belastende forhold i sakene kan vi ta som utgangspunkt at barn i alle de tre meklingskategoriene er representert i utvalget.

\subsection{Analyse av data og teoretisk rammeverk}

Analysespørsmål er den serie med spørsmål som forskeren stiller til sitt empiriske materiale (Haavind, 2000). Andenæs og Sundnes (2019:229) refererer til Jackson og Mazzei (2013) og viser hvordan analysearbeidet inngår i en mer omfattende forskningsprosess. I denne prosessen formuleres analysespørsmålene i skjæringspunktet mellom forskningsspørsmålene, studiens teoretiske utgangspunkt og det som trer frem i arbeid med empirien. Vi har latt oss inspirere av en slik fremgangsmåte i våre analyser. Utgangspunktet i vår analyseprosess er forskningsspørsmålet som gir retning til hele studien. Deretter følger de overordnede teoretiske perspektivene, teoretisk og empirisk kunnskap om fenomenet som utforskes, samt kunnskap som de innledende tolkningene gir. I HBIM-studien undersøkes ulike aspekter ved

\footnotetext{
${ }^{8}$ For nærmere omtale av representativitet viser vi til Strandbu, Thørnblad og Handegård (2016:372).
} 
involvering av barn i meklingsprosessen. Et overordnet teoretisk perspektiv i studien er barndomssosiologiens forståelse av barn som sosiale aktører (James og James, 2004). Barn påvirkes av sitt miljø og utvikles og modnes biologisk, psykologisk og sosialt i en gitt kontekst, men er også subjekter som selv påvirker sine omgivelser. Barndom betraktes i dette perspektivet som sosialt konstruert. Med dette menes at hva det vil si å være barn, avhenger av sted i verden, tid i historien og forhold som kultur, kjønn og klasse (Morrow og Richard, 1996). Et annet overordnet teoretisk perspektiv er den hermeneutiske forståelsen av mening. Mening fortolkes her i spennet mellom psykologi, hvor målet er å oppnå gjenopplevelse og psykisk innlevelse med aktøren, og analyse av konteksten forstått som «situasjoner aktørene står i og den mening situasjonene har for aktørene» (Guneriussen, 1999:116). Meningsuttrykk kan altså, slik vi legger til grunn, forstås både som uttrykk for et individualistisk aktørperspektiv og noe som reflekterer en felles historisk, kulturell kontekst og hva som gir mening for aktøren i denne konteksten.

Barna i vårt materiale forstås på denne bakgrunnen som aktører som har sine subjektive erfaringer fra det å være med i prosessen rundt foreldrenes mekling. Barnas ytringer reflekterer deres individuelle erfaringer og fortolkninger fra deres samtaler med mekler, men samtidig også den samfunnsmessige konteksten de befinner seg i, noe som har med sted i verden og tid i historien å gjøre. Som Guneriussen (1999:101) skriver, subjektive motiver og mening «henger også sammen med den kulturelle og sosiale sammenhengen aktører står innenfor». ${ }^{9}$ Dette fordrer at blikket $\mathrm{i}$ analysen ikke bare vendes mot aktørperspektivet, men også mot konteksten forstått som både verdier og normer for barndom, foreldreskap, familie, samfunn og samlivsbrudd i dag. At barn har rett til å øve innflytelse når det tas beslutninger som er av betydning for deres hverdagsliv, er en del av denne konteksten.

\subsection{Analyseprosessen}

Vår fremgangsmåte i tolkning og analyse av tekstutsagnene kan betegnes som abduktiv, det vil si en veksling mellom fortolkninger drevet av empirien og teoribasert begrepsfesting. Järvinen og Mik-Meyer (2017:11) beskriver dette som en form for dialog mellom teori og data. Alle tre forfattere har bidratt $i$ analyse av data. Det første trinnet besto av gjennomlesing av alle de 134 responsene på det åpne spørsmålet, en gjennomlesing som gjorde at vi skilte ut de 24 som utgikk fra datamaterialet. I denne prosessen diskuterte vi også hvordan vi skulle

\footnotetext{
${ }^{9}$ I hermeneutikk oppfattes både tekster og språkbruk som handlinger. 
fortolke tegninger og symboler. Symboler og tegninger som for eksempel et juletre, en bil og et jagerfly inngår ikke i datamaterialet. Smilemunn, surmunn og hjerter gir imidlertid en klar indikasjon på tilfredshet eller manglende tilfredshet ved å delta i mekling, og inngår følgelig i datamaterialet. Deretter rettet vi fokus mot hvorvidt barna beskrev det å være med som positivt, negativt, eller om de stilte seg mer nøytrale. Dette kan betegnes som en kvantifisering av kvalitative data med sikte på å undersøke barns tilfredshet eller manglende tilfredshet ved involvering i mekling. Det tredje trinnet i analysene besto av nye gjennomlesninger med sikte på å definere hovedtema med tanke på hvilke meninger barn tilskriver det å delta i mekling. Vi gjorde her en kvalitativ innholdsanalyse. Slike analyser er egnet når forskeren gjør systematiske tolkninger for å hente ut mening fra et datamateriale (Schreier, 2012).

\section{Resultater}

\subsection{Barna er positive til å involveres i meklingsprosessen}

Så mange som 98 av de 111 barna (88,3 \%) ytret seg positivt om det å være med til mekling, mens 7 barn (6,3\%) ga uttrykk for negative erfaringer, og 4 barn (3,6 \%) var nøytrale i sine ytringer. Utsagnene til 2 barn (1,8\%) lot seg ikke tolke som verken positive, negative eller nøytrale. Barna som uttrykte negative erfaringer, la vekt på ulike forhold. Ett av barna mente at det var unødvendig at barna var med: «slikt som dette [mekling] burde voksne ordne opp i selv». To barn opplevde å ikke få velge selv om de skulle delta. Ett barn mente at mekler generaliserte og ikke skjønte hvordan akkurat han hadde det. Et annet barn uttrykte generell mistillit til instanser som barnevern og familievern, mens ett barn uttrykte sin misnøye gjennom et ansikt med surmunn, uten å utdype hva som hadde vært negativt.

Barna som uttrykte tilfredshet med egen deltakelse, anvendte begreper som «godt», «supert», «fantastisk», «hyggelig», «kjempegøy», «lurt», «kjempeherlig», «takk» og «tusen takk». Flere av barna uttrykte seg gjennom både tekst og ved bruk av symboler. Eksempler på positivt verdiladete ytringer er «Det var hyggelig å være her. Tusen takk for hjelpen.» «Jeg er veldig fornøyd med at jeg fikk være med og bli hørt. Setter stor pris på det. Takk (-)» 
I sine ytringer trekker de fleste av barna frem hva som var positivt for dem selv ut fra hva de føler, mener og har behov for. Noen er også opptatt av hva de mener er viktig og riktig for barn flest. Et eksempel på dette er ei jente på ni år som skriver: «Jeg syntes at barn skal være med på mekling hvis det er noe de tenker på.» Noen få legger vekt på både hva som var bra for dem selv, og hva som er bra for barn generelt. Et eksempel er jenta på 12 år som skriver: «Det er viktig at barn er med på det og det er viktig at barn kan si sin mening og hva de føler. Det var bra at jeg fikk være med å si min mening. Håper flere barn kan også være med.»

Barnas tilfredshet kan sorteres under tre hovedtemaer. Det første hovedtemaet omtaler vi som mening relatert til mekler og meklingsordningen, hvor barna evaluerer meklingsordningen de har erfart og sitt møte med mekleren. Det andre hovedtemaet er mening relatert til rettigheter. Barna tar her utgangspunkt i hva som er rettferdig, og hva de selv eller barn flest har rett til. Det tredje hovedtemaet er mening relatert til konflikthåndtering og bearbeiding. Barna uttrykker at samlivsbruddet og situasjonen de selv er kommet i, er utfordrende, og at det var bra for dem selv eller er bra for barn generelt å snakke om egne følelser og om hvordan de har det når foreldre går fra hverandre. Vår inndeling av temaer synliggjør vesentlige trekk i materialet, og gir innblikk i hvilke meninger barn kan tilskrive egen deltakelse i meklingsprosessen. De tre hovedtemaene er utledet av de variasjoner, fellestrekk og mønstre som trer frem i materialet, men er også delvis overlappende. Hvert hovedtema har nyanser og flertydigheter, noe som resulterte i flere undertemaer i analysearbeidet. Oppsummert er hvert utsagn fra barn analysert ut fra om det var en positiv, negativ eller nøytral erfaring, og videre hvilken mening det har for barn å delta. Barnas uttrykk for tilfredshet med å være involvert, slik dette lar seg organisere innen de tre hovedtemaene i analysen, presenteres nærmere.

\subsection{Mening relatert til mekler og meklingsordningen}

Utsagnene til hele 83 av de 98 barna (84,7\%) som hadde en positivt ladet ytring, kan relateres til meklingsordningen og/eller mekleren. Barna ble involvert ved første meklingstime, og de færreste hadde møtt mekleren tidligere. Eksempler på formuleringer som ble brukt $\mathrm{i}$ beskrivelsen av mekleren, var «veldig hyggelig», «hyggelig og rolig», «snill» og «flink og forståelsesfull». En gutt på 12 år skriver: «Jeg gruet meg veldig til å være med på mekling i starten, men når jeg kom hit følte jeg meg åpen og det ble veldig mye lettere for meg å si hva jeg ville fordi hun damen [mekleren] var så snill.» En gutt på 6 år skriver: «Det var hyggelig å være her. Tusen takk for hjelpa.» Flere tegner hjerter og smilemunn når de uttaler seg om mekler. De trekker frem kvaliteter ved mekleren som at mekler «sa masse fine ting», «var lett 
å snakke med», «hun forsto» og «hun forklarte». Flere av barna som uttalte seg om mekler, vektla aspekter knyttet til hjelp til å forstå, opplevelsen av å bli forstått, og også støtte i å uttrykke det som var vanskelig å sette ord på. En gutt på 7 år skriver: «Du var snill. Du var flink til å svare på spørsmålene mine.» Ei jente på 12 år skriver: «Jeg syntes at det var bra å være med. Fordi at mekleren kunne forklare meg ting. Og forsto det jeg mente og sa.»

Enkelte barns utsagn gir inntrykk av at mekler og meklingsordningen fasiliterer en ramme for samtalen som balanserer makt og regulerer emosjoner, noe som på ulike måter oppleves som positivt. Et eksempel er en gutt på 14 år som skriver: «Jeg vil si at det er en veldig bra måte å få diskutert på. Jeg har en far som kan bli høylytt og sur, det er litt derfor meklingen er bra, fordi han vil prøve og være snill når mekleren er der. Ett problem er å lyve foran mekleren som faren min gjorde.» Et annet barn uttrykte at «det føltes trygt» å være med foreldrene til mekling.

Barna har snakket med mekleren alene. Flere trekker frem at det var fint å snakke med noen andre enn mamma og pappa, og at det var fint å snakke med mekler uten at foreldrene hørte hva de sa. Ei jente på 7 år skriver: «Jeg likte å si hva jeg mente uten mamma og pappa.» Barna begrunner dette på ulike måter. Ei jente på åtte år skriver: «Det er bra for barn. For en mekler kan forklare ting på en annen måte enn foreldrene.» En gutt på ni år skriver: «Når du er hos en mekler får du si det du vil si.» Ei jente på 15 år skriver: «Jeg syntes det var veldig fint å få muligheten til å si det jeg ville, og håper dette er noe som fortsetter.» En gutt på 10 år skriver: «Jeg synes meklingen var bra fordi da fikk jeg sagt det jeg ville.» Flere trakk frem aspekter som kan fortolkes som at barna følte seg fri til å snakke i barnesamtalen.

Enkelte kom med utsagn som kan fortolkes som innspill til forbedring av meklingsmodellen. Barna var blant annet opptatt av å få god informasjon og tilstrekkelig med tid i samtalen med mekler. De rettet også fokus mot spørsmål knyttet til barns alder og sakens alvorlighetsgrad og kompleksitet. En 14-åring mente at dette burde vært en ordning for dem under 13 år, og ikke under 16, mens ei jente på 19 år mente at ordningen burde være et tilbud til barn i familier med større vansker enn i hennes familie. Ei jente på 14 år etterlyser større grad av fleksibilitet i meklingssituasjoner hvor de fraskilte foreldrene kommer svært dårlig overens: «Jeg mener at mekling kan ta hensyn til at det finnes delikate situasjoner med foreldre, som kan bli vanskelig om begge er til stede.» 


\subsection{Mening relatert til rettigheter}

Av de 98 barna som ytret positive erfaringer fra samtalen med mekler, er det nærmere halvparten, 46 barn (46,9\%), som på en eller annen måte relaterer dette til barns rett til deltakelse. Barna er opptatt av at det er rettferdig og riktig at de selv og barn generelt får si hva de mener når foreldrene skiller lag og familien skal reorganiseres. De begrepsfester retten de har til å delta, gjennom formuleringer som «å bli hørt», «få sagt hva jeg mente», «få si det du vil si», «få komme med forslag», «få vite det jeg lurte på», «være med å bestemme» og «si ting rett ut». Svært mange av barna bruker begrepet mening. Ei jente på 14 år skriver: «Jeg synes meklingen var veldig bra fordi da fikk vi som barn si vår mening og vi følte at vi ble hørt.» Ei jente på 12 år skriver: «Det er viktig at barn er med på det, og det er viktig at barn kan si sin mening og hva de føler. Det var bra at jeg fikk være med å si min mening. Håper flere barn også kan være med i det.» Flere begrunner egen og barns generelle deltakelse i mekling med at de er berørt av foreldrenes samlivsbrudd. Det som skjer eller har skjedd mellom foreldrene, handler også om deres liv, og derfor bør også de få si hva de mener. En gutt på 16 år skriver: «Jeg synes alle barn i slike forhold burde få være med på mekling ettersom at de er en del av bildet de også.» Ei jente på 13 år skriver: «Jeg synes det er bra at vi får være med på mekling fordi det er vi som må høre på all diskuteringen og da er det viktig at vi får si det vi mener.»

$\AA ̊$ ha en rett til deltakelse er ikke det samme som at barn skal bestemme selv og/eller har

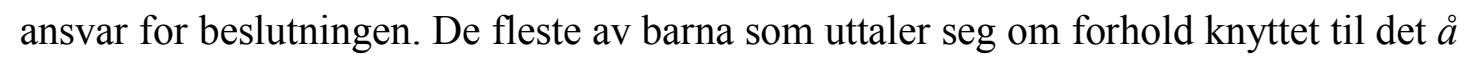
bestemme, ser ut til være innforstått med nettopp dette. Ei jente på 15 år skriver: «Jeg synes det er flott at barn kan få være med på mekling. Det er flott at de også kan få bli hørt og at de er med på å bestemme.» Ei jente på samme alder skriver: «Det er en fin plass til å få snakket om hva man tenker og mener om at foreldrene skilles. Og selv om foreldrene bestemmer til slutt så er det en fin følelse å få sagt det man mener og ha en del i bestemmelsen.» En gutt på 12 år skriver: «Jeg synes det er bra at jeg får komme med forslag.» Ei jente på ni år trekker paralleller mellom det å bestemme og det å si hva man mener: «Mekling er noe barnet burde være med på så de kan bestemme/si hva de mener.»

I BIM-modellen inviteres familien tilbake etter et halvt år for å evaluere avtalen og gjøre eventuelle endringer. Også i evalueringen gjennomføres det en egen barnesamtale hvor barn gis en mulighet til å komme med sine budskap til foreldrene. Flere av barna trekker frem som positivt at de skal få si sin mening flere ganger. Ei jente på 6 år skriver (sannsynligvis 
formulert ved hjelp av kontorpersonalet): «Jeg synes det var bra. Fordi jeg fikk vite det jeg lurte på. Synes også det er fint at vi kan komme om 6 mnd. og forklare hvordan vi har det da.» Ei jente på 13 år skriver: «Jeg vil gjerne ha det litt oftere, fordi da kan vi forandre på noe hvis det ikke funker.»

\subsection{Mening relatert til konflikthaindtering}

Det tredje hovedtemaet kan knyttes til et terapeutisk arbeid i samspill med en profesjonell hjelper. Av 98 barn som trakk frem positive erfaringer, var det 27 barn (27,6\%) som relaterte dette til egne følelsesmessige reaksjoner i situasjonen de og familien var kommet i, og/eller verdien av å få snakke med mekler om det som var vanskelig. Flere brukte formuleringer som å «få det ut», «åpne seg», «få snakket om det» og «få snakke ut». Ei jente på 12 år skriver: «Jeg synes det var litt godt å få sagt det, istedenfor å holde det inne! Mekleren vår var veldig hyggelig og rolig!» Ei jente på 10 år skriver: «Jeg syntes det er fint at barn får være med på mekling, for da får de snakket om det.» Ei jente på ni år skriver: «Jeg liker å være på mekling fordi da blir jeg ferdig med ting jeg synes er vanskelig eller ting jeg ikke liker.» En gutt på 11 år skriver: «Jeg er tom for ord fikk sagt alt (:).» Ei jente på 10 år skriver: «Det var godt å få snakke ut det jeg ville. Det hjalp veldig mye :-) Ikke noe mer $(;) . »$ En gutt på 12 år skriver: «Det er lurt. Man kan åpne seg å si alt.»

Flere av barna trakk frem som positivt at de fikk anledning til å fortelle til mekler hva som hadde skjedd. Ei jente på 12 år skriver: «Jeg synes det var bra og fint å snakke om hvordan dette har vært.» Ei jente på ni år skriver: «Det var greit. Og fint å prate. Og det var greit å fortelle om det som hadde skjedd.» Søsteren, som var ett år eldre, skriver noe lignende: «Det var greit å fortelle litt hva som har skjedd.»Ei jente på 15 år trekker frem at hun fikk hjelp av mekler til å sette ord på det hun ikke hadde et språk for: «Jeg syntes det var kjempeherlig å kunne snakke med mekleren fordi hun forsto hva jeg mente og greide å sette ord på det jeg ikke greide.» Det samme var viktig for ei jente på 12 år som var opptatt av både å få hjelp til å forstå og selv bli forstått: «Jeg syntes at det var bra og være med. Fordi at mekleren kunne forklare meg ting. Og forsto det jeg mente og sa.»

\subsection{Barnas utsagn som flertydige og tematisk overlappende}

Enkelte barn tilskriver det å delta mening på flere måter. Utsagnene fra disse barna er dermed overlappende når det gjelder våre tre analytiske hovedtemaer. Et eksempel er ei jente på 12 år 
som skriver: «Det er viktig at barn er med på det og det er viktig at barn kan si sin mening og hva de føler. Det var bra at jeg fikk være med å si min mening. Håper flere barn kan være med i det.» Jenta uttaler seg positivt om meklingsordningen, og relaterer dette til at hun selv og barn generelt gjennom dette gis mulighet til å delta (rettighetsorientering). Hun legger samtidig også vekt på betydningen av at barn får uttrykke hva de føler (konflikthåndtering).

Noen utsagn fra barna kan relateres til flere av de tre temaene. Et eksempel er når barna snakker om det å få informasjon, få hjelp til å forstå hva som skjer, og det å oppleve seg forstått. Informasjon og gjensidig forståelse er viktig i bearbeiding og konflikthåndtering når utfordringer i livet skal håndteres. Å få informasjon, forstå hva som skjer, og føle seg forstått er også viktig når barn skal delta i beslutningsprosesser.

\section{Diskusjon}

Meklingspraksisen i Norge er i endring. Ordningen med differensiering og digitalisering er innført, og et eget utvalg, Familievernutvalget, ${ }^{10}$ er i gang med en helhetlig gjennomgang og evaluering av familievernet. «Hvordan barns rett til å bli hørt og å si sin mening kan ivaretas», er formulert som et eget punkt i utvalgets mandat. ${ }^{11}$ Vi mener at resultatene fra denne studien, barnas ønske om og tilfredshet med egen deltakelse, og hva slags mening barn tilskriver det å være involvert i meklingsprosessen, er verdt å merke seg ved innføring av en ny meklingsordning og i vurdering av forslagene til Familievernutvalget. ${ }^{12}$

Svaret på vår problemstilling - hva slags mening og kvalitet er det barna tilskriver det å være involvert i meklingsprosessen - er som vist flertydig. Mange barn satte pris på at meklerne hjalp dem med å formulere sin egen skilsmissehistorie. De fleste som kommer til barnesamtalen, befinner seg i en livssituasjon preget av stor grad av omstilling. Foreldrenes samlivsbrudd kan ha kommet brått på, og det kan være vanskelig for barn å forstå hva som skjer. Barn kan føle skyld, hendelser kan oppleves som fragmentariske, og det kan oppleves

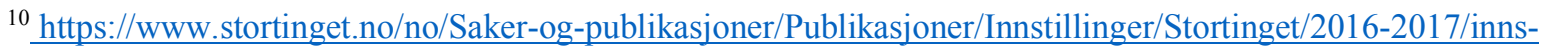
201617-014s/?all=true

${ }^{11} \mathrm{https} / / /$ www.regjeringen.no/contentassets/e98222e7e1504a83a3f3035c4420a2e7/mandat-for-gjennomgang-avfamilievernet---pdf.pdf

${ }^{12}$ I review-prosessen for vår artikkel publiserte Familievernutvalget sin utredning (NOU 2019: 20). I utredningen pekes det på at dagens juridiske rammeverk ikke sikrer barns rett til deltakelse godt nok i forbindelse med mekling. Utvalget følger anbefalingene til FNs barnekomité om at barn skal gis anledning til å høres direkte, og fremmer forslag om lovfesting av at barn skal få tilbud om å delta i mekling. Det vil si at barn inviteres med når foreldrene skal til mekling, og at barn gis anledning til å delta uavhengig av foreldrenes samtykke. Lovforslaget styrker barns rett til deltakelse i forbindelse med mekling. https://www.regieringen.no/no/dokumenter/nou-2019-20/id2678371/
} 
utrygt å ikke vite hvordan fremtiden vil bli. Opplevelsen av forutsigbarhet og sammenheng, der begripelighet, håndterbarhet og meningsfullhet er kjernekomponenter, er viktig for å mestre store livsutfordringer (Antonovsky, 1979). For å skape sammenheng kan barn ha behov for å få svar på sine spørsmål, bekreftelse på egne tanker og følelser, og hjelp til å se seg selv i sin egen livssituasjon. I tråd med Antonovskys teorier ser vi at barna i vår studie trekker frem som viktig at de fikk viktig informasjon og hjelp til å forstå, og støtte til å sette ord på følelser og meninger.

For mange barn kan foreldrenes samlivsbrudd representere en vesentlig belastning. Flere barn i vår undersøkelse opplevde å få emosjonell støtte i samtalen de hadde alene med mekler. Tidligere analyser $\mathrm{i}$ andre deler av studien viser at noen barn ikke hadde snakket med foreldrene om samlivsbruddet og familieforandringen før barnesamtalen, blant annet fordi de opplevde foreldrene som lite tilgjengelig for en slik samtale. Noen av barna forteller at de har det vanskelig, og ber mekleren om hjelp til å ta dette opp med foreldrene (Strandbu og Thørnblad, 2015). Et sentralt aspekt når det gjelder barns deltakelse, er å tilstrebe samsvar mellom barnets opplevelse av sin situasjon og den voksnes forståelse av hvordan barn har det (Sommer, 2003). Utfordringen når det gjelder å «dele» forståelsen av det barnet og den/de voksne er sammen om (jf. Sommer, 2003), blir større jo mer forskjellig barnets situasjon og erfaringer er fra den voksnes. Barn kan ha andre opplevelser av skilsmissen og etableringen av nye familieformer enn hva foreldrene tror (Haugen, 2007). Dette begrunner i seg selv at barn skal gis en anledning til å bringe frem sine opplevelser og erfaringer i forbindelse med samlivsbrudd og foreldrekonflikter. Barnesamtalen handler om at barnet skal få hjelp til å forstå og bli forstått, men også om å få støtte til å tørre å si hvordan det har det.

En kvalitet ved samtalen med mekler er videre at den styrker barns mulighet for innflytelse. Formålet med meklingen er å komme frem til ordninger til barnets beste. For flere av barna i vår undersøkelse utgjorde det en kvalitet å snakke med mekler alene uten foreldrene. Mekleren forsto og forklarte, og det føltes trygt å snakke. Den demokratiske retten til deltakelse (jf. Barnekonvensjonens artikkel 12) er en rett til fritt å gi uttrykk for sine meninger. Dette innebærer at barnet skal bestemme selv om det vil uttale seg, og eventuelt om hva (FNs General Comment No. 12, 2009, punkt 22). Barnet skal gis mulighet til å ta utgangspunkt i seg selv og bringe frem sine erfaringer, tanker, meninger og ønsker i alle forhold som vedrører barnet (Ot.prp. nr. 29 (2002-2003) s. 62). Barnets synspunkt, begrepet som anvendes i blant annet Barnekonvensjonen, er ikke alltid ferdig formulert, og barn kan 
trenge hjelp til å sette ord på og klargjøre egne opplevelser, følelser og tanker. Dette vil igjen danne grunnlaget for å tydeliggjøre egne meninger, ønsker og behov når det gjelder bosted, samvær og andre spørsmål knyttet til eget liv. Flere av barna i vår studie opplevde å få støtte til slikt meningsarbeid i samtalen med mekler. At barns meninger kommer frem, kan bidra til en mer helhetlig vurdering av «barnets beste» for hvert enkelt barn.

Et formål med innføring av digitalisering og differensiert mekling våren 2018 var å standardisere meklingspraksisen for å sikre et likt tjenestetilbud over hele landet. Året før innføringen av den nye ordningen varierte barns deltakelse i mekling fra $7 \%$ på meklingskontoret med lavest deltakelse til $57 \%$ på kontoret med høyest deltakelse. Andelen barn som involveres i meklingskonteksten, økte i tiden etter innføringen av digitalisering og differensiering i de regionene hvor barn tradisjonelt har vært mindre involvert. ${ }^{13}$ Landsgjennomsnittet for involvering av barn har gått opp fra 22 \% i 2017 (året før innføring av ordningen) til $28 \%$ i første halvdel av 2019. Differensiering av mekling har sannsynligvis påvirket kontorenes involvering av barn. Det er imidlertid verdt å merke seg at kontorer som tidligere hadde høy deltakelse av barn, har hatt en nedgang etter innføringen av differensiert mekling. Eksempelvis var barn involvert i $51 \%$ av alle meklinger ved familievernkontorene i henholdsvis Tromsø og Grenland i 2017. Dette tallet hadde sunket til $27 \%$ ved Tromsø familievernkontor og 38 \% ved Grenland familievernkontor ved utgangen av 2018.

Mye tyder på at årsaken til denne nedgangen kan knyttes til endringer i informasjonsarbeidet. Både barn i vår studie som hadde innspill til hvordan ordningen kunne forbedres, og barn som var tilfredse etter egen deltakelse, legger vekt på betydningen av informasjon. De færreste har kjennskap til hva som foregår når foreldrene skal til mekling, og hva det innebærer for barn å delta. Ved kontorer som har anvendt BIM-modellen, har barns deltakelse vært et sentralt tema når foreldrene har ringt og begjært mekling. I samtalen med foreldrene, som gir grunnlag for å differensiere mellom A, B-, C- og risikomeklinger, er ikke barns deltakelse et tema. Årsaken er at den kontorfaglig ansatte ikke kan vite hvilken kategori den aktuelle meklingen er, før samtalen med den andre forelderen er gjennomført. Dersom det er en C-mekling eller en risikomekling, skal ikke barnet inviteres med i første time. Den kontorfaglig ansatte er derfor

\footnotetext{
${ }^{13}$ Andelen barn som var involvert i mekling landet sett under ett første halvdel av 2019, var 28 \%, fordelt på $20 \%$ i Region Øst, 21 \% i Region Midt, 24 \% i Region Vest, 25 \% i Region Nord og 32 \% i Region Sør. Andelen barn som deltok landet sett under ett i 2017, året før innføringen av den nye ordningen, var $22 \%$. Det eksisterer ikke regionale tall for 2017, men tallene for 2016 var et landsgjennomsnitt på 16\%, med $11 \%$ i Region Øst, 12 \% i Region Midt, 17 \% i Region Vest, 25 \% i Region Nord og 23 \% i Region Sør.
} 
bedt om ikke å tematisere barns deltakelse i denne samtalen. En annen årsak er at differensieringsspørsmålene tar mye tid. Informasjon om barns rett til deltakelse er derfor nedprioritert. Dersom det var gitt informasjon om barns rett til deltakelse i disse telefonsamtalene, kunne det kanskje bidratt til at flere foreldre vurderte å ta med barna til første time i A- og B-meklinger.

Informasjon om barns deltakelse gis i dag elektronisk, i innkallingen til mekling. Et spørsmål som reises i meklingsfeltet, er hvorvidt et elektronisk brev leses i like stor grad som et brev som kommer per post. Formuleringer knyttet til barns deltakelse i mekling er i tillegg moderert i det elektroniske innkallingsbrevet, sammenlignet med informasjon som tidligere ble gitt i brevs form ved kontorer som anvendte BIM-modellen. Det ble der lagt ved en egen brosjyre med informasjon til barn når innkallingen til mekling ble sendt ut til foreldrene.

Den store nedgangen fra 2017 til 2018 i antall barn som involveres i mekling ved kontorer som tradisjonelt har hatt høy barnedeltakelse, har ført til endringer i informasjonsarbeidet når foreldrene ringer for å begjære mekling ved blant annet Tromsø og Grenland familievernkontor. Den kontorfaglig ansatte har vendt tilbake til tidligere praksis, og foreldrene får igjen informasjon om barns mulighet for deltakelse i denne samtalen. Etter denne endringen har Tromsø familievernkontor registrert en ny økning fra $27 \%$ deltakelse i 2018 til $34 \%$ deltakelse fra barn første halvdel av 2019. Tilsvarende økning ved Grenland familievernkontor er $38 \%$ i 2019 og $45 \%$ barn som involveres pr. 31.9.2019. At barn inviteres med til første meklingstime i A- og B-meklinger, styrker barns rett til deltakelse i forbindelse med mekling. En nedgang ved kontorer som tradisjonelt har hatt høy barnedeltakelse, er - slik dette beskrives av ansatte ved disse kontorene - en utilsiktet konsekvens av differensiering og digitalisering. Hvordan familievernkontorene kan lykkes med å gi god informasjon til foreldre og barn etter innføringen av differensiert mekling, og hvilke informasjonskanaler som er mest effektive, er en viktig problemstilling i videre praktisering av ordningen.

I den nye ordningen er det foreldrenes svar på de syv spørsmålene ved inntakssamtalen som avgjør hvorvidt barn blir invitert med til første meklingstime. I C-meklinger og risikomeklinger gis foreldre og barn ingen innflytelse med tanke på dette spørsmålet. Det er allerede bestemt at barnet ikke skal være med i første time i C-meklinger og risikomeklinger, og foreldrene og barn gis ikke anledning til sammen å diskutere hvorvidt og eventuelt når det 
er til barnets beste å få en egen samtale med mekler. Intensjonen er at mekler i de mest krevende sakene skal være bedre forberedt før gjennomføringen av barnesamtalen. Når barnet ikke involveres fra starten, vil det imidlertid være slik at foreldrene har lagt premisser for barnesamtalen, noe som ikke er tilfellet når mekler treffer barnet først. At mekler i Cmeklinger og risikomeklinger trenger å forberede seg på en annen måte enn i A- og Bmeklingene, er begrunnet $\mathrm{i}$ tanken om at det kan være belastende for barn å delta i mekling $\mathrm{i}$ familiesituasjoner med foreldrekonflikter, rus og/eller vold. Dette ønsket om å beskytte barn er i tråd med idealet i den vestlige barndommen, hvor barndommen skal være en lykkelig og beskyttet fase av menneskets liv (Stephens, 1995; Boyden, 1990). I voksenverdenen søker vi derfor å beskytte barn. Våre resultater i denne artikkelen, som underbygger resultater fra tidligere studier (Strandbu, Thørnblad og Handegård, 2016), viser imidlertid at barn ønsker å være involvert i mekling. Dette samsvarer med Skjørten (2014), som finner at de aller fleste barn benytter seg av muligheten til å uttale seg i foreldretvister i domstolene, dersom de gis anledning til det. Det interessante i vårt materiale er at barn ikke later til å ha et behov for å beskytte seg mot å snakke med mekler, heller ikke i livssituasjoner preget av konflikter eller andre belastende forhold. En av årsakene kan være at barn ofte både er kjent med og allerede involvert i foreldrenes konflikt. Av en kunnskapsoppsummering av Zemp, Bondenmann og Cummings (2016) fremgår at selv om foreldrene forsøker å skjule konflikten for barna, så lykkes de ikke med det. En annen årsak til at barn opplever det som verdifullt og meningsfullt å involveres, som vist i våre resultater, er at barna opplever møtet med mekleren og det å være involvert som svært positivt.

Barnets individuelle erfaring som aktør i denne konkrete konteksten kommer til uttrykk i tekstsvarene. Barn er ikke bare medlemmer av en familie som har sine familiepraksiser, men inngår også i større sosiale nettverk i samfunnet. Barnas ytringer gjenspeiler dermed også gjenkjennelige diskurser i samfunnet i dag når det gjelder rettferdighet, barns rettigheter og synspunkter på hva er sunt og bra for barn. Et eksempel i vårt materiale er barns utsagn om verdien av å «åpne seg» og «få snakke ut», noe som er et uttrykk for en eksplisitt form for kommunikasjon innen konflikthåndtering i vår kultur. Det reflekterer også en terapeutisk kultur i samfunnet hvor det å snakke ut og bearbeide krevende livserfaringer anses som viktig og nødvendig. Barnas utsagn reflekterer videre en anerkjennelse av barn som aktører og meningsberettigede deltakere, som etter hvert er godt etablert i Norge. Allerede i barnehagen gis barn mulighet til å påvirke sitt hverdagsliv (regulert av barnehagelovens $\S 1$ og $\S 3$ ), noe 
som fortsetter i skole og i livet for øvrig. Når barn snakker med mekleren, og blir spurt de tre spørsmålene i barnesamtalen, er det ikke første gang barnet blir møtt som aktør.

Meklingsfeltets forståelse av barns posisjon når foreldrene er med til mekling, er endret på få år. Fra at barn ikke var involvert, er holdningen i dag at barn skal inviteres med. Det er imidlertid interessant at det på styringsnivå er gjort et valg om ikke å invitere barn med til første time i C-meklinger og risikomeklinger. En forutsetning for at barn i disse meklingene får en egen barnesamtale, er at foreldrene velger å takke ja til flere meklingstimer utover den ene obligatoriske timen. Det er bekymringsverdig dersom barn, som kanskje har stort behov for å snakke med en mekler, ikke får anledning til dette, ut fra intensjonen om å beskytte barn fra potensielle belastninger.

\section{Svakheter ved datamaterialet}

Selvseleksjon av deltakere kan ha gitt skjevheter i utvalget. Samtlige som bestilte mekling, fikk tilbud om å benytte BIM-modellen, og ble forespurt om å delta i studien. Vi har ikke informasjon om dem som ikke deltok. De meklingstyper og konfliktnivåer som inngår i datamaterialet, tilsvarer imidlertid den generelle foreldremeklingspopulasjonen i Norge på tidspunktet for datainnsamlingen. Metodologisk kan vi stille spørsmål ved om empirisk materiale med korte tekstutsagn gir tilstrekkelig grunnlag for å fortolke barns opplevelser av mening ved egen deltakelse. Barnas utsagn og tolkninger av meklingskonteksten kunne gjennom kvalitative intervju blitt nærmere utdypet - og gitt et «tykkere» kvalitativt materiale. Tekstvarene fra 111 barn gir imidlertid et innblikk i hvordan barns fortolkning av egne erfaringer ga mening for deres deltakelse i denne konteksten.

\section{Konklusjon}

Barn befinner seg i ulike livssituasjoner med ulike behov i forbindelse med samlivsbrudd. De ønsker å delta, og de er tilfredse etter at de har deltatt. Barn knytter egen tilfredshet med involvering i meklingsprosessen til både mekler og meklingsordningen, rettigheter, konflikthåndtering og behov for bearbeiding. I samtalen med barna bruker mekler sitt faglige skjønn og justerer seg ut fra hva som kommer frem i barnesamtalene, noe som gjør at barnesamtalene blir svært forskjellige. Der enkelte barn vil trenge hjelp til å lage en sammenhengende og begripelig fortelling om hva det er som skjer, er det andre som har et 
behov for å fortelle hvordan de har det, og få bekreftelse på at det er vanskelig å være barn når foreldre er i konflikt. Atter andre barn trenger å bli møtt som en part i saken, som har klare meninger om hvordan han eller hun vil ha det fremover. Denne studien viser at barn som erfarer samlivsbrudd og foreldrekonflikter, kan ha behov for å snakke med noen andre enn foreldrene, uavhengig av konfliktnivået mellom foreldrene. Meklerens faglige skjønn, med justeringer og tilpassinger i møte med hvert enkelt barn, og barns ulike måter å bruke barnesamtalen på, gjør at barnets rett til både deltakelse og beskyttelse kan innfris. Barnas tilfredshet med mekleren og meklingsordningen tolker vi som et uttrykk for at meklerne i stor grad lykkes med å tilpasse innhold i barnesamtalen til hvert enkelt barns behov og den konkrete situasjonen barnet befinner seg i. Dette underbygger at det er riktig at barn inviteres med når foreldrene skal til mekling. Differensiering og digitalisering har ikke sikret alle barn den samme retten til å uttale seg ved foreldremekling.

\section{Litteratur}

Andenæs, A. og Sundnes, A. (2019). Utforskning av foreldrenes omsorg for barn. I Jansen A. og Andenæs, A. (red). Hverdagsliv, barndom og oppvekst. Teoretiske posisjoner og metodiske grep. Universitetsforlaget (s. 226-250).

Antonovsky, A. (1979). Health, stress, and coping: New perspectives on mental and physical well-being. San Francisco, California: Jossey-Bass Inc Pub.

Barnelova. (1981). Lov om barn og foreldre. LOV-1981-04-08-

7 https://lovdata.no/dokument/NL/lov/1981-04-08-7

Barne-, likestillings- og inkluderingsdepartementet (2008). Rundskriv Q-02/2008. Forskrift om mekling etter ekteskapsloven og barneloven.

Barne- og likestillingsdepartementet (2018). Tildelingsbrev til Barne-, ungdoms- og familiedirektoratet 2019.

Barne- og familiedepartementet (2002-2003). Oslo: Odelstingsproposisjon. nr. 29.

Barne- og familiedepartementet. NOU 2019:20. En styrket familietjeneste - En gjennomgang av familieverntjenesten.

Boyden, J. (1990). Childhood and the Policy Makers: A Comparative Perspective in the Globalization of Childhood. I A. James og A. Prout (red.), Constructing and Reconstructing Childhood. Contemporary Issues in the Sociological Study of Childhood, s. 184-215. London: The Falmer Press. 
Barne, ungdoms og familieetaten Region Sør (2016). Modell for barns deltakelse i meklingsprosessen

Barne-, ungdoms- og familiedirektoratet (2015). Årsrapport 2014. Hentet fra https://www.regjeringen.no/contentassets/e3c03f39789d433a9ade95467740b6ab/bufdiraarsrapport 2015.pdf Lastet ned 8.10.19

Barne-, ungdoms- og familiedirektoratet (2016a). Årsrapport 2015. Hentet fra https://www.bufdir.no/globalassets/global/nbbf/bufdir/Aarsrapport_2015.pdf Lastet ned 8.10 .19

Barne-, ungdoms- og familiedirektoratet (2016b). Opptrappingsplan for samtaler med barn $i$ mekling

Barne-, ungdoms- og familiedirektoratet (2017). Årsrapport 2016. Hentet fra https://www.bufdir.no/globalassets/global/ARSRAPPORT_2016.pdf. Lastet ned 8.10.19

Barne-, ungdoms- og familiedirektoratet (2018). Årsrapport 2017. Hentet fra https://www.bufdir.no/arsrapport2017/ Lastet ned 8.10.19

Barne-, ungdoms- og familiedirektoratet (2019). Årsrapport 2018. Hentet fra https://www.bufdir.no/globalassets/documents/arsrapport-2018.pdf Lastet ned 6.11.19

Ekeland, T.-J., og Myklebust, V.

(1997). Brukarperspektiv på foreldremekling ved samlivsbrot. Tidsskrift for Norsk Psykologforening, 34(9), 767-778.

Ekteskapsloven. Lov om ekteskap. LOV-1991-07-04-

47. https://lovdata.no/dokument/NL/lov/1991-07-04-47/KAPITTEL_1-2\#§6

Grunnloven. Kongeriket Noregs grunnlov. LOV-1814-05-

17. https://lovdata.no/dokument/NL/lov/1814-05-17-nn

FNs barnekonvensjon av 1989

FN (2009). General Comment Nr. 12. The right of the child to be heard.

Guldbrandsen, W. og Tjersland, O. A (2013). Hvordan virker obligatorisk foreldremekling ved store konflikter. Tidsskrift for velferdsforskning, vol. 16, nr. 1, 2013, side 1730. http://urn.nb.no/URN:NBN:no-53027

Guneriussen, W. (1999). Aktør, handling og struktur. Grunnlagsproblemer i samfunnsvitenskapene. Tano Aschehoug.

Haugen, G.M. (2007). Divorce and Post-divorce Family Practice: The Perspective of Children and Young People. Ph.d.-avhandling. Trondheim: NTNU.

Haavind, H. (red). (2000). Kjønn og fortolkende metode. Metodiske muligheter i kvalitativ forskning. Gyldendal Akademisk. 
James, A. \& James, A. L. (2004) Constructing Childhood: Theory, Policy and Social Practice. Routledge Education Classic Edition.

Järvinen, M. og Mik-Meyer, N. (red.) Kvalitativ analyse. Syv traditioner København: Hans Reitzels Forlag 2017

Meklingsforskriftene. (2006). Forskrift om mekling etter ekteskapsloven og barneloven. Hentet fra http://lovdata.no/forskrift/2006-12-18-1478/§2

Menneskerettsloven. Lov om styrking av menneskerettighetenes stilling i norsk rett. LOV1999-05-21-30. https://lovdata.no/dokument/NL/lov/1999-05-21-30

Morrow, V. og Richard, M. (1996). The ethics of social research with children: An overview, Children \& Society 10: 95-105

Nylund, A (2019). Children's Right to Participate in Decision-Making in Norway: Paternalism and Autonomy. Antatt for publisering i Constitutional Rights in the Nordic Countries. Bendiksen, L., Haugli, T., Nylund, A. og Sigurdsen, R. (red.) Brill.

Schreier, M. (2012). Qualitative Content Analysis in Practice. London: SAGE

Skjørten, K. (2014). Foreldretvister og økt vektlegging av barns synspunkt. Tidsskrift for familierett, arverett og barnevernrettslige spørsmål. 2, 79-81.

Sommer, $\quad$ D. (2003). Børnesyn i udviklingspsykologien.

Er et børneperspektiv mulig? Pedagogisk forskning i Sverige 8 (1-2), s. 85-100.

Stephens, S. (red.) (1995). Children and the politics of culture. Princeton: Princeton University Press.

Strandbu, A., \& Thørnblad, R. (2015). Hva står på spill? - Barns deltakelse og budskap i mekling. Fokus på familien (04), 271-291.

Strandbu, A., Thørnblad, T. \& Handegård B. H. (2016). Involvering av barn i mekling, Tidsskrift for familierett, arverett og barnevernrettslige spørsmål. Tidsskrift for familierett, arverett og barnevernrettslige spørsmål, 04/2016 (v14), 360-385.

Ulvik, O.S. (2009). Barns rett til deltakelse - teoretiske og praktiske utfordringer i profesjonelle hjelperes samarbeid med barn. Tidsskrift for Norsk Psykologforening, 46, (12), 2009, s. 1148 1154

Ådnanes, M., Haugen, G.M.D., Jensberg, H., Rantalaiho, M., og Husum, T.L. (2011). Evaluering av mekling etter ekteskapslov og barnelov. Er meklingsordningen tilstrekkelig innrettet mot de vanskelige sakene, opplever foreldrene mekling som nyttig, og er barnets beste en rettesnor for avtalen? Trondheim: SINTEF.

Zemp, M., Bodenmann, G., \& Mark Cummings, E. (2016). The significance of interparental conflict for children: Rationale for couple-focused programs in family therapy. European Psychologist, 21(2), 99-108. http://dx.doi.org/10.1027/1016-9040/a000245 


\section{Nettsider:}

https://www.kidsrightsindex.org/Portals/5/KRI\%202019/The\%20KidsRights $\% 20$ Index $\% 2020$ 19\%20Report.pdf?ver=2019-05-09-150422-647

https://www.bufdir.no/Statistikk_og_analyse/Oppvekst/Familie_omsorg_og_relasjoner/Barno og_samlivsbrudd/

https://www.stortinget.no/no/Saker-og-

publikasjoner/Publikasjoner/Innstillinger/Stortinget/2016-2017/inns-201617-014s/?all=true

https://www.regjeringen.no/contentassets/e98222e7e1504a83a3f3035c4420a2e7/mandat-forgjennomgang-av-familievernet---pdf.pdf

https://www.regjeringen.no/no/dokumenter/nou-2019-20/id2678371/ 